\title{
A Survey: The Role of Research and Development in Securing the Effective Transfer of Technology
}

\author{
Israa Ezzat Salem $^{1 *}$, Alaa Wagih Abdulqader ${ }^{2}$, Marwa M. Ismaeel ${ }^{3}$ and Maad M. Mijwil ${ }^{4}$ \\ 1,2,3,4 Computer Techniques Engineering Department, Baghdad College of Economic Sciences University \\ Baghdad, Iraq \\ *Corresponding author's email: sraa.ezzat [AT] baghdadcollege.edu.iq
}

\begin{abstract}
The investment and progress made in the transfer of technology by the Gulf cooperation council (GCC) countries to industrialize their countries are briefly reviewed. About 31.42 billion US\$ was spent between, and 2005 to 2015 establish over 3280 industrial operating plants. Manufacturing industry and other sectors contribution to national income has increased significantly. However, serious difficulties and obstacles still face the GCC industry, and these are specified and reported. The status and level of expenditure of $R \& D$ were low, and the present $R \& D$ system is deficient. These might have been partly responsible for the above industrial problems. Arab countries spent $0.76 \%$ of their GNP on $R \& D$ in 1989 compared to $2.92 \%$ of GNP by developed countries. The expenditure on $R \&$ $D$ is increased by $10 \%$ for the same period. Examples of indigenous $R \& D$ showed success in achieving innovative technologies because the environment for $R \& D$ was right. Some corrective measures to present $R \& D$ systems are recommended.
\end{abstract}

Keywords - About four key words or phrases in order of importance, separated by commas

\section{INTRODUCTION}

The last few decades have witnessed a quantum leap forward in technological advancement. The application of these new technologies resulted in new opportunities to develop human forces to exploit natural sources for the betterment of human lives and to improve economic deployment [1]. This age of science and technology was realized partly because of the heave investment made on $\mathrm{R} \& \mathrm{D}$ activities, which made the technological innovations possible that started in the 20th century [2]. Also, heavy investments were made over a long period to build the necessary infrastructure.

The developing countries in general and the Arab world countries in particular, have also made modest progress in industrialization [3]. This progress occurred because of the intense competition among the world sellers of technologies and the desire by developing countries to improve the lifestyle of their societies by proper and effective utilization of their indigenous natural resources using modern technologies [4]. Consequently, huge sums of money have been invested by developing countries and especially GCC countries for the transfer of technologies for the industrial and technological development of their countries [5]. However, despite the progress made in industrialization, serious obstacles and difficulties still face the industrial process in GCC countries. This might be attributed partly to the low level of R \& D involvement in the process of transfer of technology [6]. Therefore, the subject of this paper is to review and analyze the relationship between $\mathrm{R} \& \mathrm{D}$ and the transfer of technology and provide some recommendations to strengthen it [7].

\section{OBJECTIVES}

The main objectives of this paper are [8]:

1-To briefly review the progress made in Transfer of technology to industrialize GCC countries and some of the difficulties and obstacles facing these industries.

2- To review the status and level of expenditure of R \& D systems in the Arab World and specify its main deficiencies.

3- To show the results of an indigenous $\mathrm{R} \& \mathrm{D}$ when the right environment is provided and its success in yielding innovative technologies.

4- To recommend some corrective measures to improve the efficiency of the present R \& D system and emphasize its role in securing the effective transfer of technology, leading to technological self- reliance.

5- The Quest for transfer of technology by GCC countries.

\section{HISTORICAL BACKGROUND}

Before the discovery of oil and gas in the Arabian Gulf Region in the 1930s, the people of these countries lived rather poorly. Since petroleum is almost the only source of income, the GCC countries put strategic plans to diversify their 
sources of income and to maximize the utilization of the oil revenues [9]. The plans were instituted with the objectives of building the infrastructure to support the transfer of technology and to provide the necessary services and to develop the critical mass that is needed. The GCC countries started with the importation of technologies that are not only import substitution but are also export oriented industries [10]. These industries can be classified as light, and heavy industries and the technologies used are of the standard - modern type technologies. Industrialization of GCC Countries [11]:

The following is a very brief account as to the progress made in industrializing the GCC countries and it will only cover the progress made in petroleum and petroleum-related industries since these industries are the dominant industries in the region [12]. Industrialization started with energy-intensive industries because of the abundance of gas and oil in the GCC countries. Oil refining was the first industrial sector that came to address local and regional needs [13]. The amount of refined crude oil and the export of refined products have doubled over the last decade. The local consumption of refined products is almost doubled too. This indicates the increased use of these products in the petrochemical industry. While the petroleum industry started in the 1930s and grew and developed in the 1940s and 1950s, the petrochemical industry is relatively new, and it only started in 1970s [14]. And as in developed countries [15]. The petrochemical industry in GCC countries is going in two stages. The first stage is the production of basic chemicals while the second stage is the conversion of basic chemicals into intermediate products which can be converted into final products for consumption. Big petrochemical companies were established in the late 1970s. For example, Saudi Basic Industries company or SABIC was established in 1976 and went on production stream in 1983. Today SABIC provides about $3-4$ $\%$ of world petrochemicals market [6][12]. Other petrochemical companies have also been established in GCC countries like Qatar petrochemical company, which is a joint - venture company with CDF Chemise of France. In addition to the above major national companies, lots of private industries have also been established throughout the region. These companies are moving into downstream products. Few investment companies are also showing a frenzy of activities in investing and supporting this important sector [16]. In general, the GCC petrochemical industry has progressed very well over the past decade. They are becoming export-oriented industries, which are the cornerstone toward industrialization [17]. The share of the GCC petrochemical industry in the world production capacity ranges between almost $1 \%$ to $8 \%$. This was, of course, made possible because of the huge investment made over the past two decades by the GCC governments. For example. According to Saudi consulting House (4), the number of chemical plants in Saudi Arabia grew from 24 in 1970 to 274 in 2005 with a total investment of 14.4 billion US\$ which is $47 \%$ of the total investment on industries in Saudi Arabia [10][11].

Other industries have also been established throughout the GCC countries. For the last 15 years, the number of total operating plants in the GCC countries has increased from 1626 plants to 4905 plants [18]. This tripling in the number of plants came after the oil prices boosted in 1973. The largest part of the investment expenditure of the GCC countries was on the transfer of these technologies. The total amount of investment in these plants for all the GCC countries is about 35.545 million US dollars in 2005 compared to 4.125 million in 1975 [18][19].

Consequently, the number of employees has increased from 48.000 to 273.329 over the same period. As to the national manpower involvement, SABIC's statistics show, for example, that $60 \%$ of the total labor force working in SABIC are Saudi nationals. Table 1 shows the industrial development in GCC countries from the years 2005 to 2015 along with the total investment and number of jobs it created.

Table 1: Industrial development in GCC countries 2005 - 2015

\begin{tabular}{l|llllll}
\hline \multirow{2}{*}{ Country } & \multicolumn{2}{l}{$\begin{array}{l}\text { No. of operational } \\
\text { plants }\end{array}$} & \multicolumn{2}{l|}{$\begin{array}{l}\text { Total investment (Million } \\
\text { US\$) }\end{array}$} & No. of employees \\
\cline { 2 - 7 } & 2005 & 2015 & 2005 & 2015 & 2005 & 2015 \\
\hline Saudi Arabia & 473 & 2310 & 2670 & 21898 & 15000 & 144872 \\
Bahrain & 120 & 338 & 403 & 1389 & 3700 & 14875 \\
Kuwait & 425 & 584 & 616 & 4626 & 15400 & 38464 \\
Oman & 138 & 406 & 81 & 1227 & 2200 & 6634 \\
Qatar & 145 & 318 & 116 & 1175 & 3500 & 13075 \\
U.A.E. & 325 & 949 & 239 & 5229 & 8200 & 55409 \\
Total & 1626 & 4905 & 4125 & 35544 & 48000 & 273329 \\
\hline
\end{tabular}

\section{REALIZATION OF SOME GCC OBJECTIVES}

The policy of GCC [20] leaders to diversify their national sources of income is finally bearing fruits. Table 2 shows the various export products and the revenues that were brought in. One very significant finding is that mineral fuel and crude oil represented $97.34 \%$ of total exports in 2005 compared to $84.4 \%$ in 2015 . This indicates the significant contribution by other sectors to the national economy of the GCC countries. Manufacturing income contribution by other sectors to the national economy of the GCC countries. Manufacturing income contribution jumped from $0.88 \%$ in 2005 to $5.12 \%$ in 2015 and chemicals also have similar trends. They jumped from $0.39 \%$ in 2005 to $5.33 \%$ in 2015 
indicating that some of the objectives set forth by the GCC leaders are being met and industrialization of a country by the measure of how much the manufacturing industry contribution is to the GDP of that country. In other words, the manufacturing industry is the yardstick for measuring the technology level of a country).

Table 2: Export and export values for various products in GCC Countries

\begin{tabular}{ccccc}
\hline \multirow{2}{*}{ Export product } & \multicolumn{4}{c}{ Export value (in millions of us\$ ) } \\
\cline { 2 - 5 } & 2005 & $\%$ & 2015 & $\%$ \\
\hline Food and beverages & 523.71 & 0.32 & 1203.62 & 1.83 \\
Crude materials & 128.73 & 0.08 & 367.62 & 0.56 \\
Mineral fuel and crude oil & 158757.44 & 97.34 & 55417.48 & 87.40 \\
Chemicals & 643.15 & 0.39 & 3497.38 & 5.33 \\
Machines and transport & 1597.15 & 0.98 & 1598.51 & 2.43 \\
Manufacturing & 1428.36 & 0.88 & 3363.82 & 5.12 \\
Others & 9.06 & 0.01 & 216.31 & 0.33 \\
Total & 163087.61 & 100 & 65664.02 & 100 \\
\hline
\end{tabular}

\section{*sources IDB GOIC.}

Difficulties and obstacles are facing GCC Industries Like all developing countries the GCC countries face difficulties and have many problems in their quest for transfer of technology despite the significant progress made toward industrialization [21]. GCC countries had access to the transfer of technology only the last couple of decades, which means that insignificant accumulation of technology has been realized in such a short period [22]. By comparison, industrialized western world had 300 years of lead time, and Japan had almost one century of technological development. Some of these difficulties and obstacles include:

1- The shortage of well-trained scientific and technical manpower. According to one reference, the time needed to train qualified scientist and technicians in a specific field is a minimum of 20 years.

2- The investment in science and technology and specifically in R \& D is very insufficient. As we shall see later, the investment of the Arab world on R \& D is very well below the world average and has declined over the past decade.

3- The lack of efficient systems for science and technology. For example, the education system is too theoretical. The $\mathrm{R}$ $\&$ D programs are very weak and ill-financed. Institutions for the dissemination of scientific knowledge are very weak R \& D I only financed by the governments and is almost non- existent in the industry. Therefore, while it is important to invest in the transfer of technology, top priority should be given to the establishment of efficient R \& D programs to enhance the transfer of technology.

4- finally, another problem facing all developing countries is the so-called pre-modern social structure. One source, who witnessed the Korean experience in industrialization, puts it this way "The development of science and technology in the West went along in parallel with a political and social modernization movement. It is a must that the customs and pre-modern way of life and social structure with its inherited irrational and unscientific way of thinking and life styles has proven to be a major obstacle to the productive importation of modern Science and Technology and their development.

5- The status of R \& D in the Arab world and GCC. It mentioned above, one of the major weaknesses of the developing countries in general and the Arab World and GCC countries, in particular, is the poor expenditure on R \& D [23]. While some say that R \& D might not help developing counties as it did to developed countries, it suffices to say that the Korean experience proved the fallacy of this theory. It has also been shown that economic growth was proportional to the amount invested in R \& D [24]. Efficient R \& D systems are essential in developing indigenous capabilities and the capacity for the proper selection, digestion and adaptation of imported technologies. While the first step is to acquire and adopt the foreign technology the ultimate success to industrialize a country depends on whether or not this technology has been assimilated and adapted to the local social and economic conditions of that country. This cannot be achieved without proper and efficient R \& D system that is a prerequisite for technological self - reliance on absorbing and developing technological know-how and skills. It is reported that a threshold level of $1 \%$ of GNP investment in R \& D is necessary to achieve any results from $\mathrm{R} \& \mathrm{D}$.

\section{EXPENDITURE ON R \& D WORLDWIDE}

Although the exact amount of expenditure on R \& D in the Arab world is very hard to find, a recent publication by UNESCO gives an estimation for it [25]. Table 3 shows the estimated numbers for scientists and Engineers engaged in $\mathrm{R}$ $\& \mathrm{D}$ and the expenditure invested in it for the years 2005, 2015 and 2005. The following conclusions can be drawn from the table:

1- Developed countries spent $2.92 \%$ of their GNP in 2015 compared to only $0.64 \%$ of GNP spent by the developing countries and $0.76 \%$ of GNP spent by the Arab countries for the same year.

2- Developed countries expenditure on R \& D grew by $31.53 \%$ of their GNP in the last decade, while the Arab countries expenditure on R \& D declined by $21.88 \%$. Similarly, the average world expenditure as \% of GNP on R \& $\mathrm{D}$ over the last decade increased by $37.84 \%$ compared to an increase of $23 \%$ for the developing countries and 47.52 $\%$ for the Asian countries excluding the Arab states in Asia. 
3- Figure 1 and two were constructed using the data in Table 3 to show the trends for the next decade using approximately the same growth rates of the past decade. It can be seen that the gap is widening between the developing countries and the Arab world and those of the developed countries. It can be deduced from figure 2 that the Arab world share of R \& D expenditure in 2005 is about $0.7 \%$ of the world expenditure compared to $4 \%$ for developing countries, $18.3 \%$ for Japan, $23.2 \%$ for Europe, $42.8 \%$ for North America and $96 \%$ for the developed world. If the same growth rate of $\mathrm{R} \& \mathrm{D}$ expenditure continues for the next decade, the share of developing countries in $\mathrm{R} \& \mathrm{D}$ would certainly diminish.

Table 3: Scientist and engineers engaged in R \& D and expenditure for R \& D: Estimates for 2005, and 2015

\begin{tabular}{|c|c|c|c|c|c|}
\hline \multirow{2}{*}{$\begin{array}{l}\text { Continents, major } \\
\text { Areas \& Groups of } \\
\text { countries }\end{array}$} & \multirow[b]{2}{*}{ Year } & \multicolumn{2}{|c|}{ R\&D scientists \& engineers } & \multicolumn{2}{|c|}{ R \& D expenditure } \\
\hline & & $\begin{array}{l}\text { Estimated number per } \\
\text { million populate }\end{array}$ & Estimated & $\begin{array}{l}\text { Estimated amount (in } \\
\text { millions of USS ) }\end{array}$ & As $\%$ of GNP \\
\hline \multirow[t]{3}{*}{ World total } & 2005 & 3920754 & 894 & 208370 & 1.85 \\
\hline & 2010 & 4402867 & 920 & 271850 & 2.22 \\
\hline & 2015 & 5223614 & 1000 & 452590 & 2.55 \\
\hline \multirow[t]{3}{*}{ Africa } & 2005 & 51324 & 111 & 1081 & 0.28 \\
\hline & 2010 & 56761 & 106 & 921 & 0.25 \\
\hline & 2015 & 73081 & 117 & 1139 & 0.25 \\
\hline \multirow[t]{3}{*}{ America } & 2005 & 774922 & 1268 & 70431 & 1.85 \\
\hline & 2010 & 925648 & 1390 & 118944 & 2.35 \\
\hline & 2015 & 1093653 & 1509 & 196581 & 2.87 \\
\hline \multirow[t]{3}{*}{ Asia } & 2005 & 788034 & 310 & 31726 & 1.40 \\
\hline & 2010 & 954034 & 342 & 47188 & 1.77 \\
\hline & 2015 & 1229512 & 401 & 91218 & 2.05 \\
\hline \multirow{3}{*}{ Europe } & 2005 & 893482 & 1859 & 70712 & 1.81 \\
\hline & 2010 & 940351 & 1927 & 65540 & 2.02 \\
\hline & 2015 & 1091003 & 2206 & 104956 & 2.21 \\
\hline \multirow[t]{3}{*}{ Ocemia } & 2005 & 39692 & 1774 & 2147 & 1.25 \\
\hline & 2010 & 34173 & 1414 & 2115 & 1.20 \\
\hline & 2015 & 41965 & 1610 & 2984 & 1.38 \\
\hline \multirow[t]{3}{*}{ u.s.s.r } & 2005 & 1373300 & 5172 & 32273 & 4.69 \\
\hline & 2010 & 1491300 & 5385 & 37143 & 5.03 \\
\hline & 2015 & 1694400 & 5892 & 55712 & 5.66 \\
\hline \multirow[t]{3}{*}{ Developed countries } & 2005 & 3452128 & 3038 & 195798 & 2.22 \\
\hline & 2010 & 3834251 & 3267 & 258834 & 2.62 \\
\hline & 2015 & 4463798 & 3694 & 434265 & 2.92 \\
\hline \multirow[t]{3}{*}{ Developing countries } & 2005 & 468626 & 144 & 12571 & 052 \\
\hline & 2010 & 568616 & 158 & 13016 & 0.57 \\
\hline & 2015 & 759816 & 189 & 18325 & 0.64 \\
\hline \multirow{3}{*}{$\begin{array}{c}\text { Africa (excluding Arab } \\
\text { states ) }\end{array}$} & 2005 & 29353 & 84 & 784 & 0.30 \\
\hline & 2010 & 29364 & 72 & 620 & 0.28 \\
\hline & 2015 & 34963 & 74 & 746 & 0.29 \\
\hline \multirow{3}{*}{$\begin{array}{c}\text { Asia (excluding Arab } \\
\text { states ) }\end{array}$} & 2005 & 758533 & 304 & 28199 & 1.41 \\
\hline & 2010 & 920763 & 336 & 44024 & 1.80 \\
\hline & 2015 & 1190369 & 396 & 88533 & 2.08 \\
\hline \multirow[t]{3}{*}{ Arab states } & 2005 & 51472 & 330 & 3824 & 0.97 \\
\hline & 2010 & 61268 & 336 & 3465 & 0.94 \\
\hline & 2015 & 77261 & 363 & 3078 & 0.76 \\
\hline \multirow[t]{3}{*}{ Northern America } & 2005 & 688020 & 2734 & 66796 & 2.23 \\
\hline & 2010 & 80253 & 3024 & 115882 & 2.66 \\
\hline & 2015 & 77261 & 363 & 3078 & 0.76 \\
\hline \multirow[t]{3}{*}{ Northern America } & 2005 & 688020 & 2734 & 66796 & 2.23 \\
\hline & 2010 & 800253 & 3024 & 115882 & 2.66 \\
\hline & 2015 & 930722 & 3359 & 193721 & 3.16 \\
\hline \multirow{3}{*}{$\begin{array}{c}\text { Latin America and the } \\
\text { Caribbean }\end{array}$} & 1980 & 86901 & 242 & 3635 & 0.44 \\
\hline & 2010 & 125395 & 312 & 3062 & 0.43 \\
\hline & 2015 & 162930 & 364 & 2860 & 0.40 \\
\hline
\end{tabular}

Source: Enesco statistics on science and technology in October 2006 
As for the number of scientists and engineers engaged in R \& D, the estimated numbers for the years 2005, 2005 and 2015 are also shown in Table: 3 The data shows that:

1- There is an estimated $363 \mathrm{R} \& \mathrm{D}$ scientists and engineers per one million of the population in the Arab world compared to 1000 per million for the world average and 3694 per million for developed countries 189 per million for the developing countries.

2- While the total estimated numbers of professionals for the Arab World has increased by $50.1 \%$ over the last decade the actual numbers per million of the population only increased by $10 \%$ compared to $11.9 \%$ for the world average and $21.6 \%$ for developed countries and $31.3 \%$ for developing countries.

3- The per cent increase in the total number of scientists was higher in the Arab world than most other countries. The per cent of professional staff per million populations is lower because of the population in the Arab world increased from 156 million in 1980 to 213 million in 2015 or an increase of $36.50 \%$ compared to $23.5 \%$ increase for developing countries over the same time.

4- The data also shows that if the trend continues with the same growth rate, the gap between Arab countries and the rest of the world is going to widen as it is evident from figure 3. It should also be noted that the number of technical personnel per million of the population in a country is one of the measures of technological capability of that country for industrialization.

In Figures 1 and 3 we have added the data for the Republic of Korea to show the phenomenal progress made by this developing country. While the expenditure on R \& D by Korea reached about $2.3 \%$ of their GNP and the number of scientists and engineers reached about 1680 per millions of population in 2015 the Korean government is planning to spend $5 \%$ of GNP on R \& D expenditure and increase their number of scientists and engineers per millions of population to 3300 by the year 2001. Figure 1 shows that if the planned R \& D expenditure for Korea is realized and if the current spending rate continues for the rest of the world then Korea will be number one by the year 2001 in terms of R \& D expenditure. It should be remembered that Korea's expenditure on R \& D was only $0.2 \%$ of their GNP in the early 1960s, and it looks Korea only three decades to reach to self - sufficiency and self- reliance in almost all of its industries. The Korean experience in the transfer of technology and industrialization should be an example to all developing countries who wish to be industrialized. R \& D expenditure was one of the man factors for Korea's success.

Expenditure on R \& D by some world private Industry

A recent special issue of international Business week reported that the total U.S.A., industry spending on R \& D in 2015 reached 74 billion US dollars which is an increase of $3.4 \%$ and as a per cent of pretax profits reached $46.8 \%$. It should be noted that the total USA spending on R \& D for 2015 reached almost 144 billion dollars.

Table 4 shows the top ten companies in the USA and what they spend and R \& D compared to the top ten foreign companies throughout the world. The huge spending on R \& D by the foreign industry stems from their strong conviction that $\mathrm{R} \& \mathrm{D}$ is the key to their survival in this competitive world. This is one of the reasons why some of these giant companies have opened R \& D centers abroad to attract foreign talents and to open new markets. The Arab world expenditure on $\mathrm{R} \& \mathrm{D}$ is also shown in Table 4 for comparative purposes.

Table 4: Top to U, S. and international companies in R \& D Spending in 2005

\begin{tabular}{cccc}
\hline International companies & Millions of US dollars & U.S. companies & Millions of US dollars \\
\hline Siemens & 4.132 & General motors & 5.342 \\
Hitachi & 3.011 & IBM & 4.914 \\
Matsushita Elec. & 2.423 & ford motor & 3.558 \\
Industrial & & AT \& T & 2.433 \\
Philips electronics & 2.411 & Digital equipment & 1.614 \\
Alcatel Alstom & 2.237 & General electric & 1.479 \\
Fujitsu & 2.097 & Du Pont & 1.428 \\
Toshiba & 1.864 & Hewlett - Packard & 1.367 \\
Nippon telegraph \& & 1.739 & & \\
telephone & & Eastman Kodak & 1.329 \\
NEC & 1.728 & Dow chemical & 1.136 \\
Bayer & 1.699 & Arab World ** & 3.078 \\
& & & \\
\hline
\end{tabular}

*Business week / Dec. 2, 2005 Unesco. Statistics on science \& technology, 2005.

Deficiencies of the R \& D systems in the Arab World:

Finally, if one examines the science sand technology systems in general and R \& D systems in particular in the Arab world, one finds the following deficiencies:

1- There is a weak relationship between universities, Industry and Research Institutions.

2- The research in universities is scattered and lacks clear objectives and bears no relationship to the needs of the industry or national goals 
3- Most of the industry management have shown little interest in the value of R \& D, and most have no clear objectives beyond just their current production plans. Another characteristic of the industry is that they are after very quick profits and very quick results and therefore they are not interested in long term R \& D

4- Highly Qualified R \& D oriented scientists and engineers are very few, and this is due to many factors including the so-called "Brain - Drain "that results from the migration of Arab scientists to developed countries. It is estimated that over 300.000 of Arab brains have migrated abroad in the Table 4.

Last twenty years with a total investment by the Arab countries of over 20 billion dollars.

The mass migration of Arab Scientists and Engineers and the inefficient R\&D activities of the Arab world institutions are occurring because of several reasons:

a- The proper atmosphere for R \& D and creativity does not exist

b- The incentives and reward systems for creativity are also very much absent.

c- There are no clear national plans for R \& D with clear objectives and goals.

d- The weak nesses that are inherited in our learning institutions. The graduates of tomorrow are not very well qualified to apply their knowledge to actual industrial problems, simply because they were not trained for it

e- The absence of "Centers for transfer of technology "in which these centers can encourage and implement the results of indigenous innovations that result from indigenous $\mathrm{R} \& \mathrm{D}$

\section{Results of some indigenous $R$ \& $D$ in GCC countries}

\section{Purpose:}

This section was chosen as a case study to demonstrate the following points:

1-The effectiveness and how fruitful it can be when cooperation between Research institution - industry - and financial institution exists.

2- If the proper environment for R \& D is found, then creativity and innovations become possible.

3 - The best way to address local needs and problems is by developing local $\mathrm{R} \& \mathrm{D}$

4- The industry needs and has lots to gain from indigenous R \& D.

5- R \& D can be costly, but the returns in terms of national manpower development, utilization of local raw materials to produce added value products, avoiding stiff licensing terms and addressing local needs could be worth the expenditure on $\mathrm{R} \& \mathrm{D}$

6- The existing system for the utilization of indigenous new and innovative technologies that result from indigenous $\mathrm{R} \&$ $\mathrm{D}$ is either non-existent or very ineffective.

Background:

Kuwait Melamine industries company (K MIC) was producing melamine before its liquidation in 1983. They were producing and selling pure melamine and were interested in diversifying their products line. They approached an industrial company in West Germany (i.e. SKW) to buy a license to manufacture melamine - based super plasticizer as a concrete admixture. The SKW company agreed but with intolerable KISR and requested it to conduct R \& D and develop the product for them.

The R \& D program started in 1982 in KISR with a token financial contribution from the company and partial funding from Kuwait Foundation for Advancement of Sciences (KFAS). The research program was conducted in two phases and was concluded in three years. Both laboratory and pilot plant scale studies were conducted, and the final products were tested in the field by commercial companies.

Result of R \& D

The results were excellent. Four patents were registered and issued in the USA, covering new products and novel technologies. The direct cost for this research was about three-quarter of a million US dollars. The following is a very brief account of these new products and novel technologies.

The first product is a concrete additive or "Super plasticizer ". Its main function is to improve the workability and strength of concrete and improve its mechanical properties so it could stand the severe environmental conditions in the Arabian Gulf region. A process was also developed and patented to recover melamine from the waste effluent stream and convert it to an effective super plasticizer.

This research activity has generated further research in four more patents that were also registered and issued in the USA. These patents covered new products and processes including the development of a soil stabilizer to prevent soil erosion, a drilling mud additive from improving mud effectiveness and stability and a polymeric hydrogel or water absorber to conserve water consumption in agriculture.

Another research activity included the development of "nutritional plastic films "that can be used as mulch films in agriculture to improve the yield of crops and be degradable. Two patients were also registered and were issued in the USA and other countries [26].

The above-patented technologies are available for licensing. Some local and international companies have already shown interest. But all of these contacts were made on a personal basis.

In summary, a total of ten patents were registered in the USA as a result of an indigenous R \& D. All the patented technologies are of the applied research type, and feasibility studies proved their feasibility. The Return On Investment 
(ROI) for all these products is more than $40 \%$. They all utilize local raw materials for their manufacturing [27-30]. All of these technologies address local needs and problems. Also, the products can meet international standards and hence, they can also be exported. Unfortunately, a system to utilize and implement these novel technologies does not exist either in the Arab world or in the GCC countries.

\section{DISCUSSIONS AND CONCLUSIONS:}

We have seen that over the past two decades, huge investment and modest progress have been made in the area of transfer of technology and industrialization of the Arab Gulf region. We have also seen the difficulties and shortcomings of such an endeavor and the advantages of indigenous R\& D in meeting these difficulties and future challenges. The future trends of science and technology and the problems created by them place special emphasis on the role of R \& D for the Arab world in general and the GCC countries in particular. For the GCC countries to cope with future challenges and to protect their investments and natural resources. The demand for an efficient R \& D system becomes a must, and she would be treated as a top national priority. Coping with new advanced technologies, clean environmental demands, new materials and processes, protecting existing markets and finding new ones, meeting stiff world technological competition for new markets and new specialty products can only place a special urgency on the Arab world to start reexamining and reorganizing their R \& D systems to meet these challenges. The results of indigenous R \& D that were presented are good examples to meet some of these challenges. The existing expenditure on R \& D by the Arab world is far below the world average, and so is the number of active scientists and engineers per millions of populations. If the present trend continues for the next decade, the gap between the Arab world on the one hand and the developed, as well as the developing countries, on the other hand, will widen. The Korean experience should be studied very carefully, and some lessons should be learned if the Arab world is striving for technological self- reliance.

\section{RECOMMENDATIONS}

The following are some recommendations that are worth looking into:

1- Strengthening the R \& D system by properly equipping the research labs and staffing them with highly qualified professionals.

2- Setting national plans for R \& D with clear goals and objectives and synchronizing between various research bodies to achieve their goals

3- Increasing the expenditure on R \& D to reach at least $1.5 \%$ of GNP by 2015 and $2.5 \%$ of GNP by the year 2000 .

4- Creation of new research institutions each specializing in a specific field suitable to the local needs and environment.

5- Creation of Science and Engineering Research Centers throughout existing universities and Research institutions each specializing in a specific research area and create the proper mechanism for synchronization and dissemination of information

6- Creation of proper atmosphere for people involved in R \& D and attract creative brains and stop "Brain - Drain "phenomena in the Arab world.

7- Creation of centers for transfer and development of technology.

8- Enactment of laws to implement indigenous R \& D results by industry and encourage them through easy loan terms and some tax exemptions and provide other incentives as well.

9- Encouraging and fostering the spirit of creativity and innovations through rewards and other incentives.

10- Development of awareness programs on science and technology through the press media, seminars, television, exhibitions and others.

11- strengthening the relationship between government - universities - Research institutions and industry.

12- creation of new industrial information centers and strengthening existing ones for the sake of dissemination of industrial and technological information.

13- Increasing the R \& D manpower from the current level by enforcing science and technology curriculum in graduate schools of natural sciences and engineering

14- Repatriating as many renowned overseas Arab scientists who have long years of experience in R \& D and reverse Arab - brain migration.

15- Promoting international technical cooperation.

16- Setting up policies and developmental plans and passing laws to enforce the above recommendations.

\section{REFERENCES}

[1] Choi, H.S., "Bases for science and technology promotion in developing countries, " Nordica International Limited, Japan, 2012.

[2] Bhagavan, M.R., "The technological transformation of the third world: strategies and prospects, "Zed Books Ltd., UK, 2015.

[3] Amessea, F. and Cohendet, P., "Technology transfer revisited from the perspective of the knowledge-based economy". Research Policy vol.30, pp.1459-1478, 2011.

[4] Bartol K.M. and Srivastava A., "Encouraging knowledge sharing: the role of organizational reward systems, " Journal of Leadership \& Organizational Studies Vol. 9, No. 1, pp.64-76,2002. 
[5] Bhatt, G., D., "Knowledge Management in Organizations: Examining the Interaction between Technologies, " Techniques, And People, Journal of Knowledge Management, vol.5(1), pp.68-75,2001.

[6] Fong, P.S.W. and Lo, L.C., "Sharing Knowledge across Professional Boundaries in the Architectural Services Department, CIB 2005 Joint Symposium." Combining Forces: Advancing Facilities Management and Construction through Innovation, 13-16 June, Helsinki, Finland, 2005.

[7] Jones, R.W. and Ruffin, R.J., "The Technology Transfer Paradox", Journal of International Economics, Vol. 75, pp.321-328,2008.

[8] Lee K., Woo H. and Joshi K., "The Role of Absorptive Capacity in Partnership Retention, “Asian Journal of Technology Innovation, vol. 20, pp.155-169,2012.

[9] Leng W., "Study on Knowledge Sharing Mechanism in Open Virtual Learning Communities, "International Journal of Business and Management, Vol. 4, pp.104-108,2009.

[10] T. Hayashi, "Effect of R\&D programmers on the formation of university- industry-government networks: comparative analysis of Japanese R\&D programmers". Research Policy, vol. 32, pp. 1421-1442 (2003).

[11] Hodge G.A. and Greve G., "Public- Private Partnerships: An International Performance Review". Public Administration Review, vol. 67, pp. 545-558,2007.

[12] S.K. Markham, "Moving Technologies from Lab to Market”. Research Technology Management, vol. 45, pp. 31-42, 2002.

[13] Palvia, P., Palvia, S., and Whitworth, J. E., "Global Information Technology: A Meta-Analysis of Key Issues," Information \& Management, 39, pp.403-414, 2002.

[14] Prospects for the petrochemical industry in the Arab Gulf countries. GOIC October 2013.

[15] Areddy A. T., "Germany's BASF: China Critic, Investor,” The Wall Street Journal, December 18, 2010,

[16]Lin H.F., Effects of Extrinsic and Intrinsic Motivation on Employee Knowledge Sharing Intentions, Journal of Information Science, Vol. 33, pp.135-149,2007.

[17] Renzl, B., Intellectual capital reporting at universities- the Austrian approach. International Journal of Learning and Intellectual Capital, vol.3, pp.293-31,2006.

[18] Panteli N. and Sockalingam S., Trust and Conflict Within Virtual Inter-Organizational Alliances: A Framework for Facilitating Knowledge Sharing, Decision Support Systems, Vol. 39, pp.599-617,2005.

[19] "Industrial Espionage a Growing Threat," The Local, April, 2011, http://www.thelocal.de/national/ 2011041634433.html.

[20] Known, O. K., "The status and policy directions of technology transfer and development in Korea," presented at Tech. Tans 2007 Seoul "Korea. 2008.

[21] The quality imperative, international Business week, special issue, number 3232 - 562 McGraw - Hill publications, 2009.

[22] M.S. Haque, "Governance based on partnership with NGOs: implications for development and empowerment in rural Bangladesh”. International Review of Administrative Sciences, vol. 70, pp. 271-290, 2004.

[23] Smith K.G., Collins C.J. and Clark K.D., "Existing Knowledge, Knowledge Creation Capability, and The Rate of New Product Introduction in High-Technology Firms," Academy of Management Journal, 48 (2), pp.346-357,2005.

[24] Rogers, E. M., Takegami, S. and Yin J., Lessons Learned about Technology Transfer" Technovation, vol. 21: pp.253-261,2001.

[25] Sazali, A.W., and Raduan, C. R., The Inter Firm Technology Transfer in Malaysia - A Holistic Approach. Saarbrucken: VDM Verlag Publishing,2011.

[26] Argote L., Ingram P., Levine J.M. and Moreland R.L., Knowledge transfer in organizations, Organizational Behavior and Human Decision Processes, vol.82, pp.1-8,2000.

[27] Stephen J. Ezell and Scott M. Andes, “ICT R\&D Policies: An International Perspective, ” IEEE Internet Computing, vol.14,2010.

[28] Salem, I. E., Salman, A. M., and Mijwil, M. M., “A Survey: Cryptographic Hash Functions for Digital Stamping," Journal of Southwest Jiaotong University, vol.54, no.6, pp.1-11, December 2019, https://doi.org/10.35741/issn.0258-2724.54.6.2.

[29] Qader, A.W.A., Salem, I.E. and Abdulshaheed, H.R., 2020. A new algorithm for implementing message authentication and integrity in software implementations. Telkomnika, 18(5), pp.2543-2548, 2020.

[30] Salman, A.M. and Salem, I.E., "Improving best route using intelligent Ad Hoc system", Periodicals of Engineering and Natural Sciences (PEN), 7(2), pp.824-833, 2019.

[31] Mijwil, M. M. and Salem I. E., "Credit Card Fraud Detection in Payment Using Machine Learning Classifiers," Asian Journal of Computer and Information Systems, vol.8, no.4, pp:50-53, 29 December 2020, https://doi.org/10.24203/ajcis.v8i4.6449

[32] Mijwil, M. M., and Abttan R. A., "Artificial Intelligence: A Survey on Evolution and Future Trends," Asian Journal of Applied Sciences (AJAS), vol.9, no.2, pp:87-93, 29 April 2021. , https://doi.org/10.24203/ajas.v9i2.6589 